\title{
世界中で見つかつた「雨をつくる」細菌
}

\section{'Rain-making' bacteria found around the world}

\section{ある種の微生物はしばしば雲に乗って旅をしている。}

doi:10.1038/news.2008.632/28 February 2008

Quirin Shiermeier

植物の霜害を引き起こす細菌は、雲の 中で雨や雪が形成される過程を促進す ることもできる。空から降ってきたばか りの雪を調べる研究は、こうした「バ イオ降水」が、これまで考えられてい たよりもはるかに一般的に起きている 可能性があることを明らかにした。

雨や雪が降るためには、雲の中で雨 滴や氷の粒子が形成されなければなら ない。そのためは、凝結核となる微粒 子（エアロゾル）が必要となる。こう した粒子のほとんどは鉱物に由来して いるが、空中に漂っている細菌や菌類、 小さな藻などの微生物も、同等の働き をすることができる。鉱物性のエアロゾ ルとは異なり、生物性のエアロゾルは $0{ }^{\circ} \mathrm{C}$ に近い比較的高い温度でも、雨や 雪の形成を触媒することができる。

水核活性をもつ微生物が降水に及ぼ す影響は、これまで謎に包まれていた。 雲の中でこうした微生物を発見できな かったことも、その大きな原因となっ ている。

\section{雲の中の粒子を数える}

今回、ルイジアナ州立大学 (米国バ トンルージュ) の微生物学者Brent Christnerが率いるチームは、北米、 ヨーロッパ、南極大陸で、中 ·高緯度 のさまざまな地点で降ってきたばかりの 雪を採集し、これらを調べて、雨をつく る微生物を分類した。

彼らはサンプルの雪をフィルターに通 し、分離した粒子を容器の中の純水に 混ぜてゆっくりと温度を下げていき、ど の時点で水が凍ったかを詳細に観察し た。サンプル中に含まれる核となる粒 子の個数が多くなり、生物性の粒子の 比率が高くなるほど、凝固点は高くな る。この 2 つの効果を分離するために、 チームはサンプルを熱または化学薬品
で処理して水中の細菌を殺してから、 再びサンプルの凝固点を調べた。

Christnerらはこの方法で、溶けた 雪 1 リットルにつき 4 〜 120 個の水核 形成粒子を見つけた。これらの粒子の うち 69 〜 100 パーセントがおそらく 生物性である。この結果は、2月 29 日にScience 誌にて発表された 1 。

研究者たちは、すべてのサンプルに 「雨をつくる」細菌が含まれていたこ とに驚いた。南極大陸の雪にさえ、フ ランスや米国モンタナ州の雪よりは少 ないものの、いくつかの細菌が含まれ ていた。この結果は、微生物が雲に乗っ て長い距離を運ばれることができるとい う説に新たな証拠を追加した。また同 時に、こうした微生物が、地球上のあ らゆる地域で雨や雪の核となって降水 を誘発している可能性を示唆している。

「我々は、雲の中にある最も活性の高 い触媒の一部をほとんど無視していた という事実に気づかされたのです」と Christner はいう。「実際、生物性の 粒子は、降雪および降雨に関して非常 に重要な役割を果たしているように思 われます。その働きが特に重要になる のは、雲の温度が比較的高いときです」。

\section{水の循環と微生物}

雨をつくる細菌のほとんどは、病原体 として生きている。こうした細菌は、比 較的高い温度で凝固を促進する能力を 利用して、餌とする植物の細胞壁を破 壞している。一部の科学者は、細菌が もつこの凝固能は、雲に乗った細菌が 速やかに地上に戻ることを可能にして おり、微生物にとって有利に働いている と指摘する。

英国イーストアングリア大学の地球 システム科学者であるTim Lenton は、「こうした生物が空中から地上に

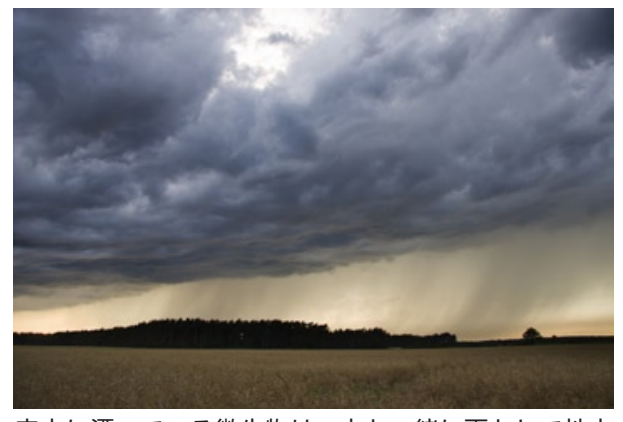

空中に漂っている微生物は、水と一緒に雨として地上 に降りてくる。

降りてくるために氷核活性を利用して いる可能性は極めて高いと考えられま す」という。

雲に乗って長い距離を運ばれて降 水と共に地上に戻ってくる能力が細菌 にとって有利に䡃くという考え方は、 Lenton が故 Bill Hamilton とともに 10 年前に提案したものであり、ガイア 仮説の中で主要な役割を果たしている。 ガイア仮説では、地球上の生物と無生 物は複雑な相互作用により 1 つのシス テムを形成しており、個々の生物はその 中で調節機能を果たすことで、生物全般 の繁栄をもたらしているとされている。

人間もまた、これらの制御プロセスに 対して大きな影響を及ぼしている。単一 栽培の拡大など、土地利用や林業、農 業の変化は、空気中の微生物の構成を 変えてしまう。生物性のエアロゾルが雨 の形成に大きな役割を果たしている可 能性が高まってきたことを考えると、そ のような変化は、地球上の多くの地域 の降水や気候に影響を及ぼす可能性が ある。「大気科学者や気候学者は、その ことの意味について考えるべき時期に来 ているのです」とChristner はいう。

1. Christner, B. et al. Science 319,1214 (2008)

2. Hamilton, W. D. \& Lenton, T. M. Ethol. Ecol. Evol. 10, 1-16 (1998). 